\title{
Imperialist feminism redux
}

\author{
Saadia Toor
}

Published online: 9 October 2012

(C) Springer Science+Business Media B.V. 2012

Ever since 9/11, there has been a constant effort to build a broad consensus around the need for a sustained U.S. military presence in Afghanistan. In the early days of the war, the idea of retaliation and revenge for the attacks on the World Trade Center had an obvious appeal for a wide range of the political spectrum. The argument about protecting "our way of life" from a global network of Islamic extremists proved persuasive as well. All through this period, there was one claim which proved instrumental in securing the consent of the liberals (and, to some extent, of the Left) - the need to rescue Afghan women from the Taliban. As the United States begins to draw down its troops in Afghanistan, we have begun to see variations of the same argument emerge once again from a variety of constituencies both within the United States and internationally. In this brief paper I undertake to identify and analyze the deeply problematic position of one such constituency which locates itself on the left-liberal spectrum in the United States and consists of an alliance between self-defined left-wing feminists in the United States and prominent feminists from the Global South (specifically Muslim countries such as Algeria and Pakistan). ${ }^{1}$ In doing so, I seek to outline the position of this new feminist front so as to offer those opposed to the war-and US imperialism more generally-some

1 http://www.guardian.co.uk/commentisfree/2012/jun/05/nato-realpolitik-afghan-women.

\section{S. Toor $(\bowtie)$}

Department of Sociology, Anthropology and Social Work, College of Staten Island, City University of New York, New York City, NY, USA

e-mail: saadiatoor@yahoo.com 
historical and political context that might prove useful in understanding and ultimately challenging its arguments.

The past 11 years of war and occupation in the name of women's rights should have served as a cautionary tale for how easily liberal (and left-liberal) guilt can be used to authorize terrible deeds, especially in view of the clear evidence showing that the status of Afghan women has seriously declined during the last 11 years largely as a consequence of the war/occupation, and in the face of consistent critiques of the occupation by Afghan (women) activists such as Malalai Joya. ${ }^{2}$ Instead, the idea that the US/NATO war in Afghanistan has been good for Afghan women continues to hold sway within the liberal mainstream in the United States. In August 2009, for example, Time magazine's cover featured a disfigured young Afghan woman with the caption, "What Happens When We Leave Afghanistan." 3 More recently, in May this year, Amnesty-USA ran a campaign openly supportive of the US/NATO presence in Afghanistan just in time for the NATO summit in Chicago. Ads on city bus stops featured images of Afghan women in burqas along with the caption: Human Rights for Women in Afghanistan. NATO: Keep the Progress Going! Alongside this ad campaign, Amnesty conducted a "shadow summit" featuring former secretary of state Madeline Albright, with promotional material rehashing Bush-era "feminist" justifications for the war in Afghanistan and claiming that the 11 years of war and occupation had improved conditions for Afghan women. ${ }^{4}$

What explains this "politically expedited collective amnesia" (Dabashi 2006) which allows Afghan/Muslim women to be constantly dredged up in order to support military adventures? Hamid Dabashi argues that a new breed of native informants is central to constantly refreshing this notion in order to legitimize the

\footnotetext{
${ }^{2}$ Of course, these voices remain marginalized within the mainstream media. See the various interviews with Malalai Joya where she articulates her critique of the US occupation and the idea that it has liberated the women of Afghanistan: http://www.malalaijoya.com/dcmj/component/customproperties/tag.html? tagId=3,http://www.thenation.com/blog/163866/malalai-joyas-message-10th-anniversary-afghanistanwar\#, http://www.abc.net.au/worldtoday/content/2012/s3471657.htm.

3 http://www.time.com/time/covers/0,16641,20100809,00.html.

${ }^{4}$ http://www.amnestyusa.org/news/press-releases/amnesty-international-hosts-shadow-summit-withafghan-women-s-rights-leaders-as-nato-summit-opens-ma. Smith (2012) has shown the startling similarity between Amnesty-US's language in these materials and that of NATO ("Amnesty for Occupation?") and laid out the details of the recent regime change within Amnesty-USA that is responsible for the pro-NATO turn. http://socialistworker.org/2012/08/08/amnesty-for-occupation (last accessed 8/16/2012). See also Kolhatkar and Rawi (2009), http://www.alternet.org/ story/141165/why_is_a_leading_feminist_organization_lending_its_name_to_support_escalation_in_ afghanistan (accessed 8/16/2012). See also, Evans (2012) and Saba (2012), http://www.alternet.org/story/ 156303/why_i_had_to_challenge_amnesty_international-usa\%27s_claim_that_nato\%27s_presence_ benefits_afghan_women;http://www.viewpointonline.net/for-amnesty-international-occupation-iswomen-liberation.html.
} 
contemporary imperialist project. In particular, Dabashi draws attention to "a body of memoire by people from an Islamic background," which has flooded the US market since $9 / 11$, and which is characterized by "legitimate concerns about the plight of Muslim women in the Islamic world," but in order to "put that predicament squarely at the service of the US ideological psy-op, militarily stipulated in the US global warmongering" (Dabashi 2006). Ayaan Hirsi Ali's Infidel (2007) and Irshad Manji's The Trouble with Islam (2004)—both bestsellers-exemplify this genre.

The fact that the meme of the Muslim woman who must be saved from Islam and Muslim men - through the intervention of a benevolent Western state-11 years after the very real plight of Afghan women was cynically deployed to legitimize a global war, and long after the opportunism of this imperialist feminism was decisively exposed, points to a serious and deep investment in the assumptions that animate these claims. These assumptions come out of a palpable dis-ease with Islam within the liberal mainstream and portions of the Left, a result of the long exposure to Orientalist and Islamophobic discourses ${ }^{5}$ that ideologues such as Bernard Lewis have continuously fed for several decades, ${ }^{6}$ and that is being supplemented and affirmed by a new generation of intellectuals, many of them trading on their "authenticity" as Muslims. It is now "common knowledge" that Islam is uniquely misogynist and homophobic and that this is a result of the essential illiberalism of a religion that has never undergone a "Reformation."7 Within this liberal discourse, secularism is posited as the necessary prerequisite for achieving equal rights for women. ${ }^{8}$

\footnotetext{
5 This liberal Islamophobia can also be found within Muslim majority countries; it comes from a legitimate anxiety over the increasing hegemony of the religious right wing; in cases such as Pakistan, which I shall come to presently, this hegemony exists within the public sphere despite religious parties repeatedly failing at the polls and is complemented by the increasing power of militant sectarian groups.

${ }^{6}$ Dabashi also astutely notes that Lewis has the dubious distinction of having shilled for both the British and the American empires. http://weekly.ahram.org.eg/2006/797/special.htm (accessed 8/16/2012).

7 This view of Islam is an integral part of FBI training. See Ackerman (2011) http://www.wired.com/ dangerroom/2011/09/fbi-muslims-radical/. See in particular the helpful chart explaining why Islam is a uniquely violent religion: http://www.wired.com/images_blogs/dangerroom/2011/09/fbi_militancy_ charts.pdf. For a historically grounded critique of this idea, see Abbas (2007), http://emc. eserver.org/1-6/abbas.html (last accessed 8/16/2012).

${ }^{8}$ The history of Europe is pointed to as the paradigmatic example of how secularism enabled women's emancipation. Wendy Brown and Joan Scott have argued that the actual relationship between the two was actually quite contentious. "Is Equality Secular?", Joan Scott and Wendy Brown, Conversations in the Humanities: The Sacred and the Secular, Center for Humanities, the Graduate Center of the City University of New York, March 6, 2009. Crucially, democracy is often seen as a problem for securing such liberal rights within the Arab/Muslim world. The less-than-enthusiastic support for the Arab Spring by liberals on the basis of a fear that the Muslim Brotherhood would come to power (thereby implying that the human rights/women's rights record of the regimes they were replacing was somehow better) illustrates the liberal anxiety regarding democracy when it comes to the Arab/Muslim "world" and hints at the historical relationship between women's movements and authoritarian regimes in the postcolonial period (which I examine in the latter part of this paper).
} 
The idea that Afghan/Muslim women are uniquely in need of saving-along with the understanding of Muslim men as uniquely patriarchal-has become a persistent meme, resistant to the range of critiques and arguments (ethical, political, and empirical) put forward to refute it. ${ }^{9}$ As is the case with stereotypes more generally, this can only be explained by the ideological work it performs. James Baldwin asked, "Who is a Nigger?", arguing that the answer to this question lays in determining who needed "the Nigger" and for whom was "the Nigger" a necessity. Like "the Nigger," the "dangerous Muslim" (who is usually male) plays a part in upholding today's project of the consolidation of a racialized world order. ${ }^{10}$

Despite the existence of a very real gendered racial project at the heart of the War on Terror, and the mainstream acceptance of the violence that it enables on Muslim men in particular and Muslim communities in general (since Muslim men do not exist in a vacuum), a new front of international feminists and human rights advocates has emerged to challenge what they see as the international human rights community's inordinate focus on Muslim men as victims. They contend that the well-meaning but misplaced focus by Western human rights advocates on the humanity of the Others of the West has rendered the "Other's Others" invisible, thereby rendering them even more vulnerable. ${ }^{11}$ This focus, they argue, constitutes a betrayal of Muslim women insofar as the idea of Muslim men as victims occlude their role as perpetrators of violence against Muslim women. ${ }^{12}$

A wide variety of intellectuals endorse the view that liberal guilt (manifested variously as multiculturalism, cultural sensitivity, and a concern for the Muslim victims of the GWoT such as those incarcerated at Guantanamo) constitutes a betrayal of Muslim women as well as of human rights advocates in Muslim communities and countries fighting against Islamic fundamentalism (not just "extremism" or "militancy"). On the one hand are those who explicitly champion the militarism and anti-Muslim xenophobia of the United Stated and the West. On the other hand are the members of a newly mobilized feminist front who present themselves as left-wing veterans of anti-racist and anti-war activism within the West, as well as established crusaders for women's and human rights within Muslim-majority countries. This provides their ideas with a currency within Leftwing political and academic spaces and among those in scholarly and activist circles within the West who would not be open to explicitly neoconservative arguments. However, the fact is that there are many underlying similarities between their discourse (and policy prescriptions) and that of the anti-Muslim right wing in the West-in which I am including neoconservatives, the religious right, as well as white supremacists and nativists.

\footnotetext{
9 Abu-Lughod (2002) and Human Rights Watch (2012): http://www.hrw.org/reports/2012/03/29/i-hadrun-away.

10 James Baldwin on 'Who is a Nigger?' http://www.youtube.com/watch?v=L0L5fciA6AU.

11 The phrase is Karima Bennoune's (Bennoune 2010).

12 This was the argument made by a group of Algerian feminists in a letter to the Center for Constitutional Rights (CCR) protesting CCR's decision to take on the case of Anwar al-Awlaki, the first US citizen targeted for assassination by his own state for his political ideology. http://www.meredithtax.org/taxonomyblog/how-not-build-culture-human-rights (last accessed 8/16/ 2012).
} 
Like their right-wing counterparts, this left-wing feminist front traffics in authenticity. ${ }^{13}$ Detractors with similar ethnic and national backgrounds (and therefore equal or competing levels of "authenticity") are dismissed as "diaspora intellectuals," 14 and insofar as their work muddies the waters of an "Us versus Them" paradigm, they are presented as enablers of fundamentalism and a danger to the project of liberal secularism and thereby to Muslim women (as well as nonMuslim minorities in Muslim-majority spaces). ${ }^{15}$ Both the neocons such as Hirsi Ali and the members of this feminist front express strong criticism of Western liberals for what they see as the latter's well-meaning attempts to avoid being (considered) racist. With minor variations, ${ }^{16}$ both think that not only does this approach not work when confronting the Muslim Other, it actually enables the spread of his illiberal politics, thereby furthering the Muslim fundamentalist project of making the world over in its image. Muslim communities within the West, they argue, are incubators of fundamentalism and illiberalism, and thus controlling them (rather than pandering to them) should be the focus of all right-minded people, white or colored. The French ban on the head-scarf is thus seen as a step in the right direction, and arguments that it undermines Muslim women's freedom of choice every bit as much as the "fundamentalism" it is supposed to be fighting are brushed aside as so much naïve Western liberalism.

\footnotetext{
${ }^{13}$ Malalai Joya, of course, poses a real problem for this discourse of authenticity. Her position as a fearless political figure within a place as dangerous for progressives and women as Afghanistan has enabled her to have a moral authority even among liberals. This makes it impossible to dismiss her or smear her with charges of complicity with fundamentalists and/or naivete. But her relentless and unqualified critique of the US/NATO occupation makes it impossible to acknowledge her, even in discussions around the issue of Afghan women and the occupation. She is thus simply never brought up within this discourse, just as activists of RAWA were ignored by the same liberal media that purported to be concerned enough about the plight of Afghan women to demand a military attack on Afghanistan. Interestingly, in the eleven years since September 2001, champions of the war in Afghanistan seem to have been unable to locate an Afghan woman willing or able to effectively play the role of native informant, which might help explain the reliance on Pakistanis.

${ }^{14}$ Also referred to as 'diaspora academics'. See, for example, Zia (2011): http://www.thenews.com.pk/ Todays-News-9-65240-The-politics-of-anti-secular-scholarship (last accessed 8/16/2012); and Siddiqa (2011): http://tribune.com.pk/story/230632/rationalising-jihadi-discourse/. For a critique of Siddiqa's argument, see Khan (2011): http://tribune.com.pk/story/238528/knee-jerk-secularism-wont-solve-ourproblems/.

${ }^{15}$ Feminist anthropologists who have tried to challenge Western assumptions about Muslim women as abject victims lacking agency are singled out for attack. Saba Mahmood seems to have the dubious distinction of being something of a nemesis for this group of feminist warriors for her book The Politics of Piety (Mahmood 2004).

16 The left-liberals might consider multiculturalism a noble but misplaced idea when confronting Muslims, while members of the right wing tend to be simply scornful of any attempt to accommodate Muslims as well as minorities in general. Here it is useful to remember the important role which Dinesh D'Souza (a first generation Indian immigrant) played in consolidating the right-wing discourse around race at a crucial moment in US history. See D’Souza (1995).
} 
What is important to note is that this critique of Western liberals and international human rights organizations for their misplaced and dangerous focus on Muslim men comes at a time when Muslim men qua Muslim men continue to be the explicit target of the GWoT, ${ }^{17}$ and an anti-Muslim racism which understands all Muslim men as dangerous intensifies in North America and Western Europe. ${ }^{18}$

Two cases in particular demonstrate how these assaults on civil liberties-like all the others that have come in the wake of $9 / 11$ - are being justified today by the purported need to protect Muslim women, the United States, and the "free world" (in that order) from dangerous and illiberal Muslim men.

The first is the case of Gita Sahgal versus Amnesty International, which resulted in an international campaign of support for Sahgal by various international human rights figures as well as prominent liberals. ${ }^{19}$ In April 2010, Gita Sahgal, the then head of Amnesty International's Gender Unit resigned following differences with the organization's leadership over what she contended was Amnesty's partnership with a "Taliban supporter" as part of their campaign to highlight the human rights abuse at Guantanamo. She argued that Amnesty's decision to work with Moazzam

\footnotetext{
${ }_{17}$ Examples include but are not limited to drone attacks, detention without charge (sometimes for years) in spaces of exception such as Guantanamo but also on CIA black sites in places like Afghanistan, torture, rendition, etc. Of course, Muslim men are not the only ones who have experienced the violence of the GWoT, especially at the hands of the NATO/US forces-this is in fact one of the essential fictions of the GWoT. Women have been killed in drone strikes and at the hands of American soldiers in Afghanistan in "night raids." They also suffer indirectly when the men of their families and communities are killed, maimed, or disappeared.

18 Examples include but are not limited to racial profiling, surveillance, entrapment, the effective abrogation of the right to free speech when it comes to Muslim men, pretrial detention (sometimes for years) under draconian Special Administrative Measures, and post-trial detention in overwhelmingly majority-Muslim Communication Management Units, special hearings on Muslim radicalization reminiscent of the McCarthy era run by Republican congressman Peter King, etc. Islam and Muslims are vilified by the United States' domestic security apparatus in the most explicit of ways. The NYPD's training for new recruits, for example, showed a deeply Islamophobic documentary on a continuous loop for months (until the story was broken by the Associated Press). In the FBI's training, its counterterrorism agents are told that “main stream' [sic] American Muslims are likely to be terrorist sympathizers"; that the Prophet Mohammed was a 'cult leader'; and that the Islamic practice of giving charity is no more than a 'funding mechanism for combat.'" The training also contends that a Muslims' level of devoutness is a predictor of how violent he is likely to be and that "[these] destructive tendencies cannot be reversed." See Spencer Ackerman, "FBI teaches agents: 'Mainstream' Muslims are 'violent, radical," Wired, September 14, 2011. A report on radicalization in the West written for NYPD identifies the most essential aspects of Muslim religious behavior-visiting a mosque, saying one's prayers regularly, growing a beard as an indicator of potential radicalization (see Silber and Bhatt 2007, http://www.nypdshield.org/public/SiteFiles/documents/NYPD_Report-Radicalization_in_the_West.pdf (last accessed 8/16/2012)). In fact, according to this report, every aspect of the behavior of a Muslim (male) — even a rejection of piety and the obvious markers of Muslim-ness such as beards and even Muslim-sounding names-should be considered dangerous. In fact, ordinary activities and behavior that would normally have constitutional protection can potentially be criminalized. Indeed, thanks to the deliberately capacious language of the "material support" statute, such activities-from charitable giving (The Holy Land Foundation), to reading and translating publicly available material (Tarek Mehanna), to allowing a friend with the connections to the wrong people to crash on your couch (Fahad Hashmi)-have already been criminalized.

19 http://www.guardian.co.uk/world/2010/apr/25/gita-sahgal-amnesty-international. Note that the Human Rights Commission of Pakistan and Women Living Under Muslim Law are two of the organizations noted as supporting Sahgal. Also listed as supporters are Salman Rushdie, another liberal hawk, and Asma Jahangir and Hina Jilani, both internationally known Pakistani feminist lawyers.
} 
Beg constituted a betrayal of Afghan women, simply because of the views she claims he held (and which he denies). Amnesty contended that Beg had been given a platform on the basis of the fact that he was a former Guantanamo detainee who had been released by the United States after having been held without charge for several years. After his release, he co-founded Cageprisoners, an organization which worked to raise awareness about the plight of detainees at Guantanamo. For Sahgal, this was not enough. By her decision to go public with her opposition to Beg, she had gained a reputation among an international community of feminists as a veritable warrior against the forces of Islamic fundamentalism and the naïve liberal human rights organizations which failed to recognize the threat they posed. The fact that many members of this international feminist community were Muslim women (or, like Sahgal, from the Global South) gave her stand added legitimacy.

In another incident, the Center for Constitutional Rights was at the receiving end of the ire of a group of feminists (many of whom had joined Sahgal's campaign of protest against Amnesty International) following CCR's decision to take up the case of Anwar al-Awlaki, the first US citizen to be openly targeted for assassination for his political views by the US state. Letters of protest sent to CCR by Algerian feminists and CCR board-member Karima Bennoune accused it of having betrayed Muslim women across the world by defending a known fundamentalist ideologue. CCR's argument that the targeting of al-Awlaki on the basis of an executive decision which bypassed all due process represented a major assault on constitutional rights evidently fell on deaf ears. ${ }^{20}$

This international network of secular liberal feminists has now consolidated itself into an organization called the Center for Secular Space, headed by Gita Sahgal. The Web site of the Center explains that the impetus behind its creation was Sahgal's fallout with Amnesty International and that the CSS network is comprised of those who mobilized on her behalf. ${ }^{21}$ Meredith Tax (who, along with Karima Bennoune, ${ }^{22}$ has been a major voice in the protest of CCR) is one of the three Directors of the Center while the list of "Advisors and Officers" reads like a who's who of third world feminists. ${ }^{23}$

The Web site also undertakes to explain why the need for such a Center was felt "now," especially given that "even before 9/11, secular spaces all over the world were under siege by authoritarian religions and their state allies." The contention is that Gita Sahgal's fallout with Amnesty demonstrated that Western liberals often end up supporting dangerous ideologies in the name of "multiculturalism" and

\footnotetext{
${ }^{20}$ See Oza (2011)—http://www.counterpunch.org/2011/01/21/with-us-or-against-us/—for an early critique of Sahgal, Tax and Bennoune's positions and Akbar and Oza (forthcoming) for a more detailed engagement with the politics of this feminist front.

21 “Center for Secular Space: Why Now?", http://www.centreforsecularspace.org/.

22 http://www.guardian.co.uk/world/2010/nov/15/us-assassination-policy-rights-awlaki.

23 http://www.centreforsecularspace.org/?q=content/about-us. This list reflects the extensive and dense nature of the personal and professional connections which undergird the international feminist/women's rights community; many of these connections, networks, and institutions have their origins in the various UN meetings on women over the past few decades. The critique of the NGO-ization of human rights and women's rights work in Pakistan which I articulate later applies equally to many of these individuals and organizations.
} 
cultural sensitivity: “...just as we resist tendencies by Western powers to conciliate with fundamentalists and dictators for the sake of oil, we must be alert to tendencies among liberals to support fundamentalist projects in the name of multiculturalism." The critique of the opportunism of "Western powers" is designed to distinguish the position of the Center and its supporters from that of neoconservatives. And yet, the critique of "multiculturalism" as a well-meaning but dangerously naive (Western) liberal tendency is no different in essence from the one we find among the xenophobic right wing in North America and Europe, and or in the discourse of Hindu nationalists in India.

The Center's contention that "all over Europe ${ }^{24}$ discussions of still-existing racism have been replaced by discussions of Islamophobia" identifies the problem as "discussions of Islamophobia" rather than the increase in Islamophobia itself. The positioning of "still-existing racism" against "discussions of Islamophobia" obscures the fact that Islamophobia is the premier form of racism in Europe today and underwrites the increasing xenophobia against immigrants of different "races" and national origins. Thus, a statement which seemed at first glance to be an uncontroversial left-wing critique of culturalism is in fact a critique of the position that Islamophobia is a real problem worth addressing. ${ }^{25}$ The presence of Muslim, and specifically a Pakistani feminist, on the list of Advisors/Officers is important to note, both given the important role played by "authenticity" in the discourse of this new feminist front, and because of the special political role that Pakistani liberals have come to play within Western debates over the war in Afghanistan. ${ }^{26}$

The discourse of these feminists, while not as stridently pro-war or openly racist as that of their less-palatable right-wing counterparts, ${ }^{27}$ trades in the same tropes and arguments and deploys authenticity as a weapon to legitimize racist violence against Muslims, while undermining the work of scholars and activists engaged in genuine anti-imperialist and anti-racist work in the West. The presence of Pakistani liberals (specifically feminists) within this new front points to the former's increased visibility within mainstream and left-liberal media in the United States in recent years, which is connected to the extension of the "Afghanistan war" into Pakistan. ${ }^{28}$

\footnotetext{
${ }^{24}$ The reference to Europe is important given the intense xenophobia against immigrant Muslim populations, and the resultant Muslim-baiting that has become part of the public mainstream there-from the Danish cartoons of Muhammad, to the banning of minarets in Switzerland. This anti-Muslim xenophobia - that is, Islamophobia - is behind the rise of far-right parties across Europe, as well as rightwing terrorism exemplified by Anders Breivik's twin attacks in Oslo last year.

${ }^{25}$ For a recent account of the relationship between Islamophobia and the project of Empire, see Kumar (2012). Kumar's argument builds on the work of Edward Said, in particular his Covering Islam (Said 1981).

${ }^{26}$ The Pakistani feminist listed on the Web site is Afiya Sheherbano Zia, but the Pakistan connection goes deeper than that given the involvement of Pakistani feminists with the Women Living Under Muslim Laws consortium and other international women's rights networks.

${ }^{27}$ Overtly, criticism of US/NATO appears as part of this feminist discourse, but a closer look reveals that this criticism shows that is not aimed at the occupation of Afghanistan by NATO/US forces, but the inadequate inclusion of women into the structures and institutions set up by the occupying forces. See, for example, the petition to Hillary Clinton and the US Delegation to the Bonn Conference hosted on the CSS Web site: http://www.centreforsecularspace.org/?q=campaigns.

${ }^{28}$ The two countries were collapsed by the Obama administration into a single theater of war which has been branded as "Af-Pak."
} 
Like their counterparts in the United States, Pakistani liberals are strong supporters of the US presence in Afghanistan and of drone attacks in Pakistan's FATA region. ${ }^{29}$ For them, the fight to preserve secular liberalism often requires resorting to illiberal means, and they thus show a marked partiality for authoritarianism and for the military, as long as these are of the "secular" variety.

The liberal relationship with authoritarianism in Pakistan dates back to the Cold War era, when liberal anti-communists colluded with the state in order to undermine the Left. ${ }^{30}$ During the late 1960s, a powerful mass movement of workers and peasants brought the 10-year military dictatorship of General Ayub Khan to an end. However, by the early 1990s the organized Left was no longer a major political force within Pakistan-having first been betrayed by the Prime Minister Z. A. Bhutto, it was decisively decimated during the US-supported military regime of Zia ul Haq; whatever remained of it after Zia self-combusted following the fall of the Soviet Union. As a result, the political space within Pakistan became divided between the liberals and the religious right (both essentially right-wing forces) with the former standing in for progressive politics tout court.

The purpose of Zia's coup had been to stamp out the dangerous twin trends of socialism and secularism from within Pakistan's body politics. The regime's "Islamization project" had been designed to address both problems while also being an exercise in legitimation. However, the crushing of the Left allowed the Zia years to be remembered only as a story of the attack on secularism by the religious right.

This selective amnesia within liberal discourse had major consequences for Pakistan after the end of the Zia regime in the late 1980s. The 1990s was a period of right-wing consolidation in Pakistan-from neoliberalism in the economic and political spheres, to an increase in the influence and power of the religious right wing within Pakistani society. An important—and not oft-told—part of the story of neoliberalism in Pakistan was the "NGO-ization of progressive politics." Many of the elite liberal (and some leftist) intellectuals and activists who had been part of the anti-Zia movement established their own development, human rights or women's rights NGOs. Mass political work of the sort associated with the organized Left was abandoned in favor of project-based work tied to the demands of the international development and human rights industries. This exacerbated the divide between liberal "civil society" activists and the vast majority of the Pakistani people, especially within the context of intensifying inequality.

At the same time, the forces of religious conservatism and militancy unleashed during the Zia era continued to gain ground. The Taliban takeover in Afghanistan amplified liberal Pakistani fears, and liberal discourse, already focused on secularism to the exclusion of all other issues, became almost exclusively obsessed with the imminent "Talibanization" of Pakistan. However, predictably, these fears did not result in ideological-political work at the mass level. Even concern for the safety and rights of religious minorities did not translate into more than seminars,

\footnotetext{
29 Although, ironically, there is more complexity in American liberal opinion today over both these issues than there is among Pakistani liberals.

${ }^{30}$ For a detailed account of this, and for the story of the rise of the religious right in Pakistan (which is also the story of the marginalization and decimation of the Left), see my The State of Islam (Toor 2011).
} 
reports, and press releases. It became clear that the confrontational politics of the Zia era were an aberration, as liberals once more showed their preference for a politics of accommodation with the state, punctuated by small symbolic protests and demonstrations. ${ }^{31}$ Issues of direct relevance to the everyday lives of most Pakistanis such as the passage of draconian anti-terror laws (used against labor leaders and striking workers), the downsizing and informalization of labor, and the need for land redistribution were largely ignored. Even now, "neoliberalism" has not entered the lexicon of Pakistani liberal intellectuals and civil society activists.

The marginalization of the Left from politics and public discourse in Pakistan, and liberal abandonment of issues and political positions such as class politics, antiimperialism, and third world solidarity made it easy for these to be co-opted (in a highly corrupt form) by the religious right. This in turn made it less and less likely for these cornerstones of Leftist politics to be taken up by liberals. Those who still choose to speak in the language of a principled Left anti-imperialism, especially with regard to the "Af-Pak" war, are routinely denounced as closet Taliban supporters.

The unconditional support for this war among Pakistani liberals, including for Pakistani military operations in tribal regions, is not unprecedented. Liberals in Pakistan have shown a predilection for authoritarianism ${ }^{32}$ as long as it is of the "secular" variety, which is connected to a deep-rooted fear of the illiberal masses. ${ }^{33}$ These internal contradictions of Pakistani liberalism and the opportunism of NGObased "civil society" politics became clear after General Pervez Musharraf deposed the government of Prime Minister Nawaz Sharif in a military coup in 1999. Pakistani liberals had begun to feel threatened by the Nawaz Sharif government which, in addition to working on passing a Shariat Bill in the national parliament, had launched a campaign of harassment against human rights and women's rights NGOs in the Punjab. As a result, Pakistani liberals, particularly civil society activists, welcomed the "secular" Musharraf almost like a messiah. Many of these prominent members of Pakistani "civil society" went on to join Musharraf's cabinet and support for Musharraf, and the Pakistani military became part of the liberal mainstream in Pakistan until a national-level movement against Musharraf led by lawyers changed the political game.

The most heartening aspect of this movement was the breaking of a long period of political apathy and the emergence of an explicitly anti-military politics among a younger generation of urban Pakistanis. However, it was not long before the threat

\footnotetext{
31 That this politics of accommodation was becoming increasingly difficult because of the increased intransigence of the state is an entirely separate issue.

32 This predilection is not unique to Pakistan-across the "Muslim world," liberals (especially women's rights advocates) have felt more comfortable with secular dictatorships than electoral democracy. The most recent example of this was the lukewarm reaction to the Arab Spring within liberal circles in Pakistan as elsewhere, because of worries over the Muslim Brotherhood and what democracy would mean for women's rights.

33 This fear, and the concern for the attack on "our way of life," is essentially about maintaining class privilege, which explains the lack of interest among most civil society activists regarding questions of economic redistribution.
} 
of a Taliban takeover, and a concern with women's rights once again resulted in liberals embracing the military as savior.

Despite some initial hiccups, ${ }^{34}$ Musharraf had joined the GWoT and-like all military dictators in Pakistan before him-ultimately came to enjoy a cozy relationship with the US administration. Obama's election and the resulting refocusing of American attention on the "good war" in Afghanistan shattered this relationship, and Pakistan began to come under increasing fire within the US media for "not doing enough" in the battle against the Taliban and al-Qaeda. However, the war continued to be unpopular with the Pakistani public, and the newly elected PPP government was reluctant to squander its newly minted populist and anti-military credentials. American pressure on Pakistan reached a critical point in the early part of 2009 , when a cell phone video allegedly showing Taliban fighters in Swat flogging a young woman began circulating within liberal circles in Pakistan (and was then picked up by the international media). At the same time, reports that the Taliban were "only 60 miles from Islamabad" began to appear within Pakistani English-language newspapers. It did not take long for these two news items to have the desired result of mobilizing liberal opinion for a military operation in Swat. ${ }^{35}$

This operation displaced over two million people, and reports of serious human rights abuses by intelligence agencies and the military soon appeared but neither produced any soul searching among supporters of the operation, nor a disavowal of the military as an agent of secularism. In fact, insofar as any ambiguity exists within liberal circles with regard to such army operations, it does not amount to more than a sense that they are (like the military itself) a necessary evil. This despite the fact that the Pakistani military's relationship with the Taliban-however complex and contradictory it may be-is well documented and well known. ${ }^{36}$

Justification for drone attacks and military operations against the people of the tribal areas is sustained by claims (backed up by "social scientific research") ${ }^{37}$ that strong support exists for drone attacks among people in $\mathrm{KPK},{ }^{38}$ and arguments which draw a moral-and, in fact, literal-equivalence between suicide bombers and militarized drones. ${ }^{39}$ Pakistani liberal support for drone strikes has remained strong even in the face of a shift in world public opinion against them, and a

\footnotetext{
34 Which involved threats of blowing Pakistan back into the stone age.

35 For details, see Toor (2009): http://socialistworker.org/2009/05/22/behind-the-nightmare-in-swat (last accessed 8/16/2012), and 'Epilogue' in State of Islam (Toor 2011).

36 The author of the best-selling and authoritative book on the Taliban is Ahmed Rashid, a well-known Pakistani liberal and establishment intellectual.

37 http://www.dailytimes.com.pk/default.asp?page=2010\01\02 \story_2-1-2010_pg3_5.

38 This is, in fact, the case within the subset of (largely urban) Pukhtoons who do not live in the regions being targeted; liberals are among this subset.

39 See Hoodbhoy (2010): http://www.viewpointonline.net/drones-theirs-and-ours.html. Hoodbhoy also recently wrote a piece titled "Why I'm not celebrating US exit" (2012): http://www.viewpointonline.net/ why-im-not-celebrating-us-exit.html. He is a regular contributor to left-leaning alternative media outlets ZNet and Counterpunch. He is also a frequent guest on Democracy Now where plays the role of a progressive Pakistani commentator on matters pertaining to Af-Pak and Pakistani politics. For a critique of Pakistani liberal native informants, including Hoodbhoy, see Alam (2009), http://www.counterpunch. org/2009/12/02/native-orientalists-at-the-daily-times/.
} 
recognition that they are far from "surgical" in their precision. Behind this intransigence lies not just anxiety over "Talibanization," but a deep-rooted and Orientalist ethno-racism against the people of the tribal areas who appear in liberal Pakistani discourse only as barbaric Others. Within this discourse, all tribal menespecially those of North and South Waziristan ${ }^{40}$ - are assumed to be either actual or imminent militants, and therefore legitimate military targets. ${ }^{41}$ This, as it happens, is exactly the same logic as that of the US state. Therefore, it is hardly surprising that the recent revelation that the US State Department considers all men of military age within regions targeted by drones to be militants (unless their innocence is posthumously proved) did not excite much comment within the Pakistani liberal universe and certainly did not result in any condemnation of what amounts to collective punishment. ${ }^{42}$

The FATA region is a no-go zone for anyone from the outside, especially journalists, and so independent verification of the claims made by the Pakistani military and US State Department has been difficult. ${ }^{43}$ However, families of drone victims have gained some visibility within Pakistan and internationally through the work of a Pakistani lawyer, especially once the UK-based human rights organization Reprieve became involved in publicizing their stories. The Bureau of Investigative Journalists has also released their own numbers and names of those killed by US drone strikes in FATA, decisively challenging the US claim that only militants have been killed in these strikes. However, Pakistani liberal support for drone strikes has remained strong even in the face of a shift in world public opinion against them, and a recognition that they are far from "surgical" in their precision.

Given these politics, and the fact that their class position allows them to dominate the English-language media in Pakistan and thereby gain an international profile, it is not surprising that they are also overrepresented in the mainstream (or even alternative) media in the United States. That is, when Pakistani voices are deemed necessary in the conversation around the war in Afghanistan, thus establishing their role as native informants in the current phase of imperialism.

"President Obama and I believe that the subjugation of women is a threat to the national security of the United States." Hillary Clinton, Remarks at the UN Commission on the Status of Women, March 12, $2010 .^{44}$

\footnotetext{
40 These areas only entered the mainstream liberal Pakistani consciousness once they began to be targeted for drone attacks.

41 In fact, most Pakistani liberals regard the majority of their compatriots as either actual or imminent threats to their way of life. "Women's rights" and "secularism" within this elite liberal discourse are essentially code for "our way of life" characterized by consumerist individualism.

42 See "Secret 'Kill List' proves a test of Obama's principles and will," New York Times, May 29, 2012, http://www.nytimes.com/2012/05/29/world/obamas-leadership-in-war-on-al-qaeda.html?_r=2\&pagewanted=1 (last accessed: 8/16/2012). For a critique of the Obama administration's definition of "militant," see Greenwald (2012), http://www.salon.com/2012/05/29/militants_media_propaganda/(last accessed: 8/16/2012).

43 See Idrees (2011), http://pulsemedia.org/2011/06/14/the-magical-realism-of-body-counts/.

44 The full transcript of the speech is available at http://www.state.gov/secretary/rm/2010/03/138320.htm
} 
Even as the United States officially begins to wind down its war in Afghanistan, the GWoT-recently rebranded as the Overseas Contingency Operation by President Obama-is spreading and intensifying across the "Muslim world," and in light of Secretary of State Clinton's remarks quoted above, we can expect to hear further calls for the United States and its allies to save Muslim women. At the same time, we are seeing the mainstreaming and institutionalization of a gendered anti-Muslim racism within the West, which means that we can also expect to see more of the discourse which pits the rights of Muslim men against those of Muslim women. The left-liberal feminist front represented by organizations such as the Center for Secular Space will have a role to play in this unfolding scenario. This paper is an attempt at clarifying the terms and stakes of this emerging ideological battle.

\section{References}

Abbas, Sadia. 2007. Other people's history: contemporary Islam and figures of early modern European dissent. Early Modern Culture (6).

Abu-Lughod, Lila. 2002. Do Muslim women really need saving? Anthropological reflections on cultural relativism and its others. American Anthropologist 104(3): 783-790.

Ackerman, Spencer. 2011. FBI teaches agents: "Mainstream" Muslims are "violent, radical". Wired, September 14. http://www.wired.com/dangerroom/2011/09/fbi-muslims-radical/.

Akbar, Amna, and Rupal Oza. forthcoming. 'Muslim Fundamentalism' and human rights in the age of terror and empire.' In Gender, national security and counter-terrorism: Human rights perspectives, ed. Margaret Satterthwaite \& Jayne Huckerby. New York: Routledge.

Alam, M. Shahid. 2009. The groveling of Pakistani elites: native orientalists at the daily times. Counterpunch, December 2. http://www.counterpunch.org/2009/12/02/native-orientalists-at-thedaily-times/.

Bennoune, Karima. 2010. Remembering the other's others: Theorizing the approach of international law to Muslim fundamentalism. Columbia Human Rights Law Review 41: 635-698.

Dabashi, Hamid. 2006. Native informants and the making of the American Empire. al-Ahram Weekly, Issue 797, June. http://weekly.ahram.org.e.g/2006/797/special.htm.

D'Souza, Dinesh. 1995. The end of racism. New York: Free Press.

Evans, Jodi. 2012. Why I had to challenge amnesty international-USA's claim that NATO's presence benefits Afghan women. Alternet, July 12. http://www.alternet.org/story/156303/why_i_had_to_challenge_ amnesty_international-usa\%27s_claim_that_nato\%27s_presence_benefits_afghan_women.

Greenwald, Glenn. 2012. "Militants": Media propaganda. May 29. http://www.salon.com/2012/05/29/ militants_media_propaganda/.

Hirsi Ali, Ayaan. 2007. Infidel. New York: Free Press.

Hoodbhoy, Pervez. 2012. Why I'm not celebrating US exit. July 19. http://www.viewpointonline.net/ why-im-not-celebrating-us-exit.html.

Hoodbhoy, Pervez. 2010-2012. Drones: Theirs and ours. Viewpoint (113). November. http://www. viewpointonline.net/drones-theirs-and-ours.html.

Human Rights Watch. 2012. "I Had To Run Away" The Imprisonment of Women and Girls for "Moral Crimes" in Afghanistan. http://www.hrw.org/reports/2012/03/29/i-had-run-away.

Idrees, Muhammad. 2011. The magical realism of body counts. Pulse Media. June 14. http://pulsemedia.org/2011/06/14/the-magical-realism-of-body-counts/.

Khan, Arsalan. 2011. Knee-jerk secularism won't solve our problems. Express Tribune, August 24. http://tribune.com.pk/story/238528/knee-jerk-secularism-wont-solve-our-problems/.

Kolhatkar, Sonali, and Rawi, Mariam. 2009. Why is a leading feminist organization lending its name to support escalation in Afghanistan? Alternet, July 7. http://www.alternet.org/story/141165/why_is_a_ leading_feminist_organization_lending_its_name_to_support_escalation_in_afghanistan.

Kumar, Deepa. 2012. Islamophobia and the politics of empire. New York: Haymarket Books.

Mahmood, Saba. 2004. The politics of piety: Islamic revivalism and the feminist subject. Princeton: Princeton University Press. 
Manji, Irshad. 2004. The trouble with Islam: A Muslim's call for reform in her faith. New York: St. Martin's Press.

Oza, Rupal. 2011. With us or against us: Feminist critiques of Sahgal and Bennoune. Counterpunch. January 21. http://www.counterpunch.org/2011/01/21/with-us-or-against-us/.

Saba, Sahar. 2012. For amnesty international, occupation is women-liberation. Viewpoint, September 14. http://www.viewpointonline.net/for-amnesty-international-occupation-is-women-liberation.html.

Said, Edward. 1981. Covering Islam: How the media and experts determine how we see the rest of the world. New York: Pantheon Books.

Siddiqa, Ayesha. 2011. Rationalising jihadi discourse. Express Tribune, August 13. http://tribune.com.pk/ story/230632/rationalising-jihadi-discourse/.

Silber, Mitchell, and Bhatt, Arvin. 2007. Radicalization in the west: The Homegrown threat. New York Police Department. http://www.nypdshield.org/public/SiteFiles/documents/NYPD_Report-Radicali zation_in_the_West.pdf.

Smith, Ashley. 2012. Amnesty for occupation? Socialist Worker, August 8. http://socialistworker.org/ 2012/08/08/amnesty-for-occupation.

Toor, Saadia. 2011. The state of Islam: Culture and cold war politics in Pakistan. London: Pluto Books.

Toor, Saadia. 2009. Behind the nightmare in Swat. Socialist Worker, May 22. http://socialistworker. org/2009/05/22/behind-the-nightmare-in-swat.

Zia, Afiya Sheherbano. 2011. The politics of anti-secular scholarship. The News International, August 29. http://www.thenews.com.pk/Todays-News-9-65240-The-politics-of-anti-secular-scholarship. 